\title{
COMPARATIVE STUDY OF DOUBLY FED INDUCTION GENERATOR AND PERMANENT MAGNET SYNCHRONOUS GENERATOR IN WIND ENERGY CONVERSION SYSTEM
}

\author{
Vineet Dahiya \\ Assistant Professor, KR Mangalam University and Presently Research Scholar in EEE \\ Department Manav Rachna International University, India
}

\section{Leena G}

Professor, EEE Department, Manav Rachna International University, Faridabad, India

\begin{abstract}
ABTRACT
The objective of this research paper is to compare various types of generator used in Wind Energy Conversion system topologies. Now a days there is fast growth of variable speed WECS due to rapid advances in power electronics technologies. In present scenario there are primarily two types of generators used in WECS namely Doubly Fed Induction Generator(DFIG) used for geared operation for variable speeds and fixed speeds and Permanent Magnet Synchronous generator(PMSG) can operate gearless. As there is higher demand of power, offshore installations are gaining popularity and hence new wind turbine designs are being expected in near future, as there will be development in generators and converter design.
\end{abstract}

Keywords: Wind Energy Conversion System (WECS), Doubly Fed Induction Generator (DFIG), Permanent Magnet Synchronous generator (PMSG), Wind turbine (WT).

Cite this Article: Vineet Dahiya and Leena G, Comparative Study of Doubly Fed Induction Generator and Permanent Magnet Synchronous Generator in Wind Energy Conversion System, International Journal of Electrical Engineering and Technology, 10(3), 2019, pp. 73-79.

http://iaeme.com/Home/issue/IJEET?Volume=10\&Issue=3

\section{INTRODUCTION}

In today's world due to increase in demand of power and fast depleting resources, there is need of alternative power sources which not only meet existing power demand but also are environment friendly. There are many renewable sources such as Solar, Wind, Geothermal, Tidal etc. Out of all these sources Wind Energy is emerging as a mature technology and provides a bright, stable and limitless source of energy for maintaining the continuously 
growing energy requirements of humanity. At the end of 2017 the overall wind capacity worldwide reached to $539291 \mathrm{MW}$. Most of the countries have achieved high level of wind production by the end of 2017 such as China produces $18839235 \mathrm{MW}$ of wind energy which is $35 \%$ of total worldwide production followed by USA and Germany which produces $89077 \mathrm{MW}$ and $56132 \mathrm{MW}$ which is $17 \%$ and $10 \%$ of total worldwide production respectively. India is ranked fourth with $32848 \mathrm{MW}$ which is $6 \%$ of total worldwide production and is expected to add additional 2.5-3 GW in financial year 2019[8].Due to advancement in WECS technologies wind turbines can be installed at both on shore and offshore locations. By using new and different combinations and configurations of generators and convertors high and stable output power can be achieved. [5]. Now a days most of the wind turbines are installed in large wind farms which are located in the areas which are not connected to grid and have large storage system through batteries. Also there are WECS which are connected to grid and power is fed to grid. For generating power from wind turbines, there are two types of generators namely doubly Fed Induction generator (DFIG) and Permanent Magnet Synchronous Generator (PMSG) which are gaining popularity now a days. A comparative study on performance of these two generators are depicted in this paper $[9,16]$.

The paper is divided in to the following Sections. Section II describes the general configuration and different topologies of a wind turbine and its conversion equations. In Section III the two different types of generators commonly in use for WT systems will be listed Doubly Fed Induction Generators (DFIG) and Permanent Magnet Synchronous generators (PMSG). Section IV will highlight the performance and market trend of each generator and Section V describes conclusion.

\section{WIND TURBINE CONFIGURATION AND TOPOLOGIES}

Up to 90's fixed speed squirrel cage induction generators were in use whose rating was less than $1 \mathrm{KW}$.With the advancement in technology variable speed WT replaced fixed speed generators because of their shortcomings. The variable speed Wind Turbines are known to achieve maximum aerodynamic efficiency over a wide range of wind speeds [3]. There are two types of WTs namely Horizontal axis configuration WT (HAWT) and vertical axis configuration WT (VAWT) with latter being used in large scale, as they have blades which have diameter of $140 \mathrm{~m}$ and can rotate at a speed in range between 5 to $25 \mathrm{rpm}[21]$. The mechanical parts and the generator are mounted in a framework which is positioned high up on a tower. [11,12].Nowadays the configuration used widely is Wind Turbine with variable speed operation configuration and pitch control system is widely used in today's time [6].

WTs are systems that have the ability to transform the kinetic energy of the wind into electricity as shown in fig1. This processes possess many stages and is characterized by the fo equations given below $[4,10]$ :

The wind power which is developed by the turbine is given by equation (1)

$$
P=\frac{1}{2} C_{P} \rho A V^{3}
$$

Where $C_{P}$ is the wind power coefficient, $\rho$ is the air density (equal to $1.225 \mathrm{~kg} / \mathrm{m}^{3}$ at sea level at temperature $\mathrm{T}=288 \mathrm{~K}$ ), $\mathrm{A}$ is the area of the turbine blades in $\mathrm{m}^{3}$ and $\mathrm{V}$ is the wind velocity in $\mathrm{m} / \mathrm{sec}$. The fraction of kinetic energy which is converted into mechanical energy by the wind turbine is given by the power coefficient $C_{P}$.It is a function of blade pitch angle $(\beta)$ and tip speed ratio (TSR) ( $\lambda$ ). Tip speed ratio is the ratio of turbine blade linear speed and wind speed given by:

$$
\lambda=\frac{R \omega}{V}
$$

Substituting (2) in (1), we have: 
Comparative Study of Doubly Fed Induction Generator and Permanent Magnet Synchronous Generator in Wind Energy Conversion System

$$
P=\frac{1}{2} C_{p}(\lambda) \rho A\left(\frac{R}{\lambda}\right)^{3} \omega^{3}
$$

The corresponding output torque of the wind turbine is given by:

$$
T_{\text {turbine }}=\frac{1}{2} \rho C_{P} V / \lambda
$$

Where $\mathrm{R}$ is the radius of the wind turbine rotor $(\mathrm{m})$.

Figure (1) shows common wind conversion system layout with gearbox, generator, power electronics converters connected to the grid.

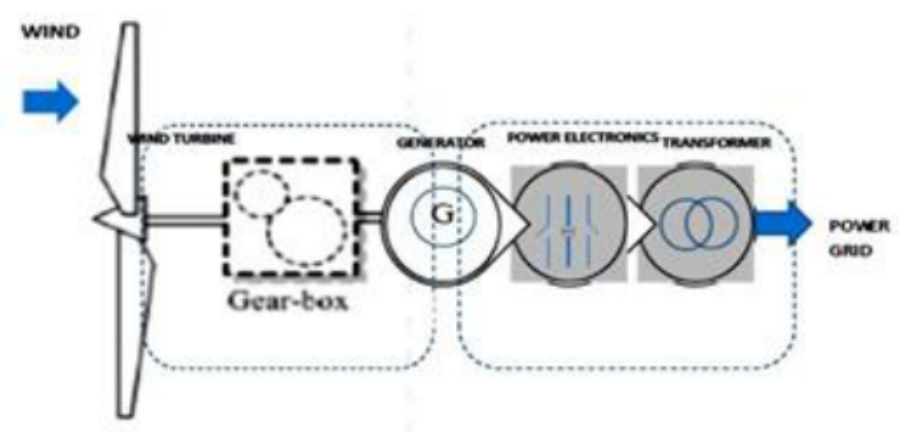

Figure 1 Wind Conversion System Layout.

Power coefficient is maximum at a specific value of tip speed ratio. Maximum power can be extracted by the wind turbine by operating the turbine at variable speed. The turbine $C_{P}$ curves are displayed in Figure 2 which follows cubic relationship.

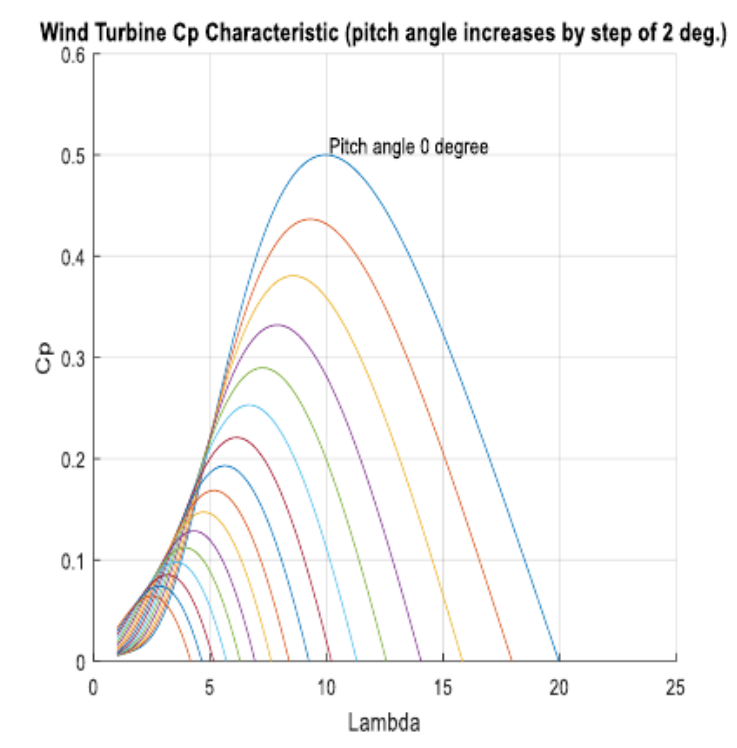

Figure 2 turbine $C_{P}$ curves

\section{GENERATOR TYPES}

In this section Induction generator and synchronous generator categories and their mathematical models will be presented and also power quality, reliability and performance of above said generators will also be discussed.

(i) Induction Generator Modeling:

The stator and rotor voltage equations are:

$$
\mathrm{V}_{\mathrm{ds}}=\mathrm{R}_{\mathrm{r}} \mathrm{i}_{\mathrm{ds}}+\mathrm{d} \psi \mathrm{ds} / \mathrm{dt}-\mathrm{s} \omega_{\mathrm{s}} \psi_{\mathrm{qs}}
$$




$$
\begin{gathered}
\mathrm{V}_{\mathrm{qs}}=\mathrm{R}_{\mathrm{r}} \mathrm{i}_{\mathrm{qs}}+\mathrm{d} \psi_{\mathrm{qs}} / \mathrm{dt}-\mathrm{s} \omega_{\mathrm{s}} \psi_{\mathrm{ds}} \\
\mathrm{V}_{\mathrm{dr}}=\mathrm{R}_{\mathrm{r}} \mathrm{i}_{\mathrm{dr}}+\mathrm{d} \psi_{\mathrm{dr}} / \mathrm{dt}-\mathrm{s} \omega_{\mathrm{s}} \psi_{\mathrm{qr}} \\
\mathrm{V}_{\mathrm{qr}}=\mathrm{R}_{\mathrm{r}} \mathrm{i}_{\mathrm{qr}}+\mathrm{d} \psi_{\mathrm{qr}} / \mathrm{dt}-\mathrm{s} \omega_{\mathrm{s}} \psi_{\mathrm{dr}}
\end{gathered}
$$

The electromagnetic torque equations and flux linkages equations are represented below:

$$
\begin{aligned}
& \mathrm{T}_{\mathrm{el}}=\psi_{\mathrm{qr}} \mathrm{i}_{\mathrm{dr}}-\psi_{\mathrm{dr}} \mathrm{i}_{\mathrm{qr}} \\
& \Psi_{\mathrm{ds}}=\mathrm{L}_{\mathrm{m}} \mathrm{i}_{\mathrm{dr}}-\mathrm{L}_{\mathrm{s}} \mathrm{i}_{\mathrm{ds}} \\
& \Psi_{\mathrm{qs}}=\mathrm{L}_{\mathrm{m}} \mathrm{i}_{\mathrm{qr}}-\mathrm{L}_{\mathrm{sl}} \mathrm{i}_{\mathrm{qs}} \\
& \Psi_{\mathrm{dr}}=\mathrm{L}_{\mathrm{m}} \mathrm{i}_{\mathrm{ds}}-\mathrm{L}_{\mathrm{rl}} \mathrm{i}_{\mathrm{dr}} \\
& \Psi_{\mathrm{qr}}=\mathrm{L}_{\mathrm{m}} \mathrm{i}_{\mathrm{dq}} \mathrm{L}_{\mathrm{rl}} \mathrm{i}_{\mathrm{qr}}
\end{aligned}
$$

Where, $v_{\mathrm{r}}, \mathrm{i}_{\mathrm{r}}$ and $\psi_{\mathrm{r}}$ represent the rotor voltage, current and flux respectively.

$\omega_{\mathrm{s}}$ represent angular velocity; $\mathrm{d}$ and $\mathrm{q}$ are the direct and quadrature axis components respectively. $\mathrm{L}_{\mathrm{m}}$ represents mutual inductance $; \mathrm{L}_{\mathrm{sl}}$ and $\mathrm{L}_{\mathrm{rl}}$ are the stator and rotor inductance.

(ii) Synchronous Generator Mathematical Model.

The PMSG is expressed by the following equations:

$$
\begin{aligned}
& \mathrm{V}_{\mathrm{ds}}=-\mathrm{R}_{\mathrm{s}} \mathrm{i}_{\mathrm{ds}}-\mathrm{L}_{\mathrm{s}} \mathrm{di}_{\mathrm{ds}} / \mathrm{dt}+\mathrm{L}_{\mathrm{s}} \omega_{\mathrm{r}} \mathrm{i}_{\mathrm{qs}} \\
& \mathrm{V}_{\mathrm{qs}}=-\mathrm{R}_{\mathrm{s}} \mathrm{i}_{\mathrm{qs}}-\mathrm{L}_{\mathrm{s}} \mathrm{di}_{\mathrm{qs}} / \mathrm{dt}+\mathrm{L}_{\mathrm{s}} \omega_{\mathrm{r}} \mathrm{i}_{\mathrm{ds}}+\omega_{\mathrm{r}} \psi
\end{aligned}
$$

Where $L_{s}$ and $R_{s}$ represent the generator inductance and stator resistance respectively, $\omega_{\mathrm{r}}$ represents generator rotor speed and $\psi$ is the magnetic flux, below is the equation of electromagnetic torque

$$
\mathrm{T}_{\mathrm{e}}=3 / 2 \mathrm{p} \psi \mathrm{i}_{\mathrm{qs}}
$$

\section{DIFFERENT TYPES OF GENERATORS}

\subsection{Doubly Fed Induction Generator}

DFIG is the most commonly used wound-rotor induction generator used in WECS as the stator of the DFIG can be directly connected to the grid and rotor across a partially rated converter [14]. Due to difference of speed between stator and rotor a gearbox is needed to couple the rotor to the generator. Most commonly used configuration includes variable frequency and back to back AC/DC/AC and AC/AC voltage source type. Rotor side and grid side convertors are used made up of power electronics devices such as IGBT, MOSFETs etc. [10]. The rotor voltage is applied from the power converters. Active and reactive powers as well as harmonics can be controlled from the Rotor Side Convertor (RSC), while power factor is controlled by Grid Side Converter (GSC) and ensures that keeps it in optimum value . A schematic of a DFIG is presented in Fig.3.

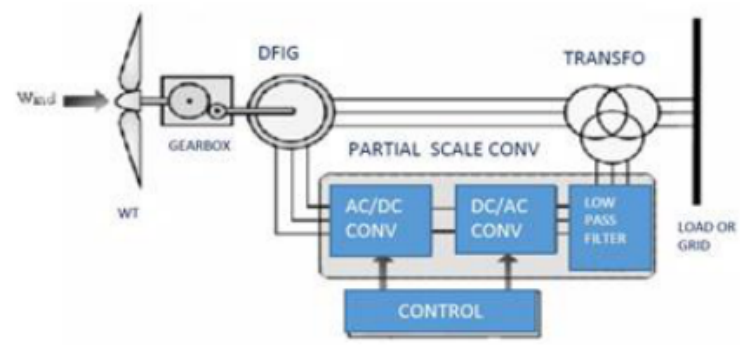

Figure 3 Schematic of a DFIG 
Comparative Study of Doubly Fed Induction Generator and Permanent Magnet Synchronous Generator in Wind Energy Conversion System

Advantages of DFIG:

- Limited speed range-30\% to $30 \%$ around synchronous speed

- Small capacity PWM inverter

- Rugged and brushless,

- Active and reactive powers can be controlled completely

- Full speed range

- High efficiency and energy yield.

Limitations of DFIG:

- There is need for gearbox.

- There is need of slip rings.

- Medium reliability and reduced longevity due to bearings and gear faults.

\subsection{PMSG (Permanent Magnet Synchronous Generator)}

By the use of PMSG it allows direct -drives systems by which the use of gearbox can be avoided and hence helps in low maintenance of the system. By using PMSG there is use of voltage source full power converter (AC/DC/AC) which helps in decoupling of generator from the grid. A schematic of a PMSG is presented in Fig.4.

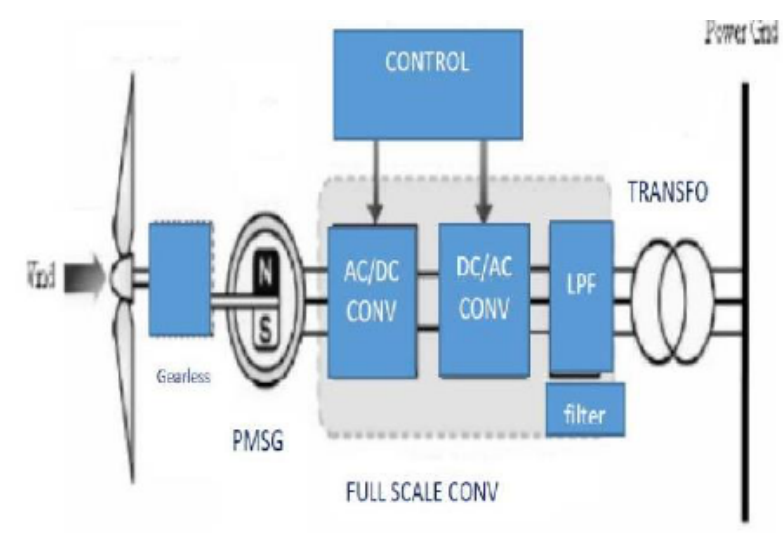

Figure 4 Schematic of a PMSG

Advantages of PMSG:

- Full speed range,

- There is no need of gear systems.

- Active and reactive powers can be controlled completely

- Brushless and have low maintenance.

- No power converter for field is required

Limitations of PMSG:

- Permanent Magnet needed

- Multipole generator is required in case of direct driven topology

- Full scale power converter.

\section{PERFORMANCE COMPARISON AND CONCLUSION:}

This paper has reviewed the technology for generators used in WECS.The efficiency of permanent magnet synchronous generator is higher than doubly fed induction generator because 
of the fact that excitation can be provided without energy supply. The other advantage of permanent Magnet Synchronous generator is that according to conditions power can be generated at any speed. The stator of the latter is wound and rotor consists of permanent magnet pole system. On the other side the materials used for manufacturing permanent magnets are expensive and also are sensitive to temperature therefore they require cooling systems. Another issue with this type of generator is problem encountered during start up due to its synchronous nature and hence there will be difficulty in getting constant voltage. Doubly Fed Induction Generator (DFIG) on the other hand has good control over generating reactive power which can be delivered to the stator by grid side converter. Due to presence of gearbox in DFIG there is additional maintenance cost and hence less reliable than PMSG. Variable speed operation is attractive in today's world because of the fact that machine with this technology exhibits more power capture and less mechanical stress.A short introduction followed by different wind turbine topologies and wind turbines from electrical point of view is presented in this paper. Analysis of Induction and synchronous generator is presented whose performances are improving due to new advancement in power electronic devices which provide solution in wind power installations by improving power system stability and control.

\section{REFERENCES}

[1] A. Tapia, G. Tapia, J. X. Ostolaza and J. R. Saenz, "Modeling and control of a wind turbine driven doubly fed induction generator," IEEE Transactions on Energy Conversion, Vol.18, pp. 194- 204.2003

[2] El-Ali, N. Moubayed et R. Outbib, “ L'éolienne : Historique, composants et principe de fonctionnement ", IEEI'08, 2nd International Symposium on the History of the Electrical Engineering and of Tertiary-Level Engineering Education, 3-5 Octobre 2008, IASI - Roumanie, Vol. 4, pp. 13-20.

[3] A.-El-Ali, J. Kouta, D. Al-Samrout, N. Moubayed et R. Outbib, "A note on wind turbine generator connected to a lead acid battery", SIELMEN 2009, 7th International Conference on Electromecanical and power systems, 8-9 Octobre 2009, IASI - Roumanie, Tome I, pp. 341-344.

[4] Babu, B. C., \& Mohanty, K. B. . Doubly-fed induction generator for variable speed wind energy conversion systems-modeling \& simulation. International Journal of Computer and Electrical Engineering, 2(1), 141,2010

[5] B. Multon, G. Robin, O. Gergaud et H. Ben Ahmed, "Le génie électrique dans le vent : état de l'art et recherches dans le domaine de la génération éolienne”, JCGE'03, Saint-Nazaire, 5 et 6 juin 2003.

[6] Dubois, M., "Optimized permanent magnet generator topologies for direct drive wind turbine", . $\mathrm{PhD}$ thesis, Delft University of Technology, Delft, The Netherlands, 2004.

[7] E.J. Bueno, S. Cóbreces, F. J. Rodríguez, A. Hernández, and F. Espinosa, "Design of a back-to-back NPC converter interface for wind turbines with squirrel-cage induction generator," IEEE Trans. Energy Convers., vol. 23, no. 3, Sept 2008, pp. 932-945.

[8] Echavarria, E., Hahn, B., van Bussel, G., Tomiyama, T.: "Reliability of wind turbine technology through time", J. Sol. Energy Eng., 2008, 130,(3), pp. 1-8

[9] F. Iov, R. Teodorescu, F. Blaabjerg, B. Andersen, J. Birk, and J. Miranda, "Grid code compliance of grid-side converter in wind turbine systems," in Proc. IEEE PESC, Jun. 18-22, 2006, pp. 1-7.

[10] H. Ahuja, G. Bhuvaneswari and R. Balasubramanian, "Performance comparison of DFIG and PMSG based WECS," IET Conference on Renewable Power Generation (RPG 2011), Edinburgh, 2011, pp. 1-6.doi: 10.1049/cp.2011.0229.

[11] H. Li, Z. Chen, "Overview of different wind generator systems and their comparisons", IET Renew. Power Gener., 2008, Vol. 2, No. 2, pp. 123-138.

[12] L. Solero, "Power Electronic converters devoted to stand-alone wind energy generating systems", EPE Journal, Vol. 12, No 2, May 2002, pp. 43-48. generation systems", Renewable Energy, Vol. 6, $\mathrm{N}^{\circ}$ 8, March 1993 pp. 907-915. 

Generator in Wind Energy Conversion System

[13] L. H. Hansen, L. Helle, F. Blaabjerg, E. Ritchie, S. Munk-Nielsen, H. Bindner, P. Srensen, and B. Bak-Jensen, "Conceptual survey of generators and power electronics for wind turbines," Risø Nat. Lab., Roskilde, Denmark, Tech. Rep. Riso-R1205 (EN), Dec. 2001.

[14] Ming Yin, Gengyin Li, Ming Zhou and Chengyong Zhao, "Modeling of the Wind Turbine with a Permanent Magnet Synchronous Generator for Integration” IEEE PES, Page(s) 1-6, June 2007

[15] Musial, W., Butterfield, S., McNiff, B., "Improving wind turbine gearbox reliability”. European Wind Energy Conf. (EWEC 2007), 2007.

[16] N.S.Patil, Y.N.Bhosle, "A Review on Wind Turbine Generator Topologies", 2013 International Conference on Power, Energy and Control (ICPEC), pp. 625-629.

[17] O. Wasynczuk, D.T. Man et J.P. Sullivan, "Dynamic behavior of a class of wind turbine generators during random wind fluctuations”, IEEE Transactions PAS, Vol. 100, No 6, 1981, pp. 2837 - 2845.

[18] R. Cardenas, R. Pena, P. Wheeler, J. Clare, and G. Asher, "Control of the reactive power supplied by a WECS based on an induction generator fed by a matrix converter," IEEE Trans. Ind. Electron., vol. 56, no. 2, Feb 2009, pp. 429-438

[19] Tavner, P., Xiang, J., Spinato, F., "Reliability analysis for wind turbines", Wind Energy, 2007, 10, pp. 1-18 generator," IEEE Trans. Energy Convers., vol. 23, no. 3, Sept 2008, pp. 932-945.

[20] Sanjiba kumar Bisoyi, R.K.Jarial, R.A.Gupta, “A Review Of The State Of The Art Of Generators And Power Electronics Converter Topologies For Wind Energy Conversion System”, International Journal of Emerging Technology and Advanced Engineering Volume 3, Special Issue 3: ICERTSD 2013, Feb 2013, pp. 283-291.

[21] S. Nasr et N. Moubayed, "Etude comparative entre éolienne ả axe horizontal et éolienne ả axe vertical ", Bulletin of the Polytechnic Institute of Jassy, Tome VII, Fascicule 5, 2011, pp. 145-157.

[22] Yi Zhang and Sadrul Ula, "Comparison and evaluation of three main types of wind turbines" IEEE PES, Vol. 1, Page(s):1-6 April 2008

[23] Z. Daneshi-Far, G. A. Capolino, H. Henao, "Review of Failures and Condition Monitoring in Wind Turbine Generators”, XIX International Conference on Electrical Machines - ICEM 2010, Rome., pp. 1-6 